\title{
PROBLEMATYKA WOŁOSKA W TWÓRCZOŚCI JERZEGO AKROPOLITESA*
}

\author{
ANNA KOTŁOWSKA
}

\begin{abstract}
The Image of Vlachs in the works of Georgios Akropolites.
The writings of Georgios Akropolites, both in historiography as well as in rhetoric, do not contain much information about Vlachs. Their presence is always secondary to the description of other events, judged through the perspective of the interests of the Palaiologan dynasty. Nevertheless, the few references to Vlachs are of significant value from the point of view of historical geography, being helpful especially when it comes to understanding the application of the term of so-called "Vlachia" (in different variations) to certain areas of northern and western Greece. Presented paper contains: a) an overview of the entire works of Georgios Akropolites, b) translated excerpts from Akropolites' main work History, together with a philological and historical commentary, c) an annex containing notes on significance of references to Vlachs in the literary masterpiece of the Cretan Renaissance, the Erotokritos written by V. Kornaros, for historical research.
\end{abstract}

StReSzCZENIE. Twórczość Jerzego Akropolitesa, zarówno z zakresu historiografii, jak i retoryki, nie zawiera wiele informacji na temat Włachów. Ich obecność jest zawsze drugorzędną wypadkową w opisie innych wydarzeń, ocenianych z perspektywy interesów dynastii Paleologów. Niemniej, nieliczne wzmianki o Włachach mają dużą wartość z zakresu geografii historycznej, będąc pomocne zwłaszcza w rozumieniu stosowania pojęcia tzw. „Wlachii” (w kilku odmiankach) na niektóre obszary Grecji północnej i zachodniej. Przedstawiony artykuł zawiera: a) przegląd całości twórczości Jerzego Akropolitesa, b) przetłumaczone fragmenty z dzieła Akropolitesa pt. Historia, zaopatrzone w komentarz filologiczno-historyczny, c) aneks, w którym umieszczono krótkie uwagi o wartości dla badań historycznych wzmianek o Włachach w arcydziele literackim kreteńskiego renesansu, Erotokritosie W. Kornarosa.

Keywords: Vlachs, Vlachia, Thessaly, Georgios Akropolites, Vitsentzos Kornaros

Słowa kluczowe: Własi, Wlachia, Tesalia, Jerzy Akropolites, Witsentzos Kornaros

Autorka: Anna Kotłowska, Uniwersytet im. Adama Mickiewicza w Poznaniu, Wydział Historii, ul. Uniwersytetu Poznańskiego 7, 61-614 Poznań, anna_kotlowska@wp.pl, ORCID iD: https://orcid.org/0000-0002-6547-806X

Balcanica Posnaniensia. Acta et studia, XXVIII/1, Poznań 2021, Wydawnictwo Wydziału Historii UAM, pp. $51-63$

ISBN 978-83-66355-68-2, ISSN 0239-4278. Polish text with summaries in English and Polish

doi.org/10.14746/bp.2021.28.3

* Artykuł powstał w ramach projektu NPRH Wolosi w europejskiej i polskiej przestrzeni kulturowej. Migracje - osadnictwo - dziedzictwo kulturowe (Projekt nr 0604/NPRH3/H12/82/2014). 


\section{WPROWADZENIE}

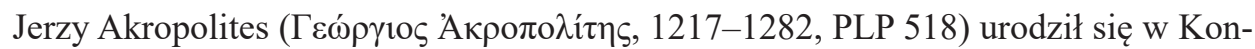
stantynopolu. Nazwisko 'Akropolites' związane z posiadaniem domu w stolicy, sięga końca $\mathrm{X}$ w. ${ }^{1}$ Bliżsi przodkowie Jerzego, w tym i jego ojciec, należeli do średniej warstwy urzędników cywilnych. ${ }^{2} \mathrm{~W} 1233$ wyjechał z rodziną do Nicei, przyczyną był najprawdopodobniej bliżej nieokreślony konflikt ojca z łacińskimi zwierzchnikami. W państwie Laskarysów rozpoczął studia (1234 r.), opłacone ale i ściśle nadzorowane przez cesarza, w elitarnej grupie liczącej razem pięć osób. Był uczniem Teodora Heksapterygosa i Nikefora Blemmydesa (Historia, par. 32). Wyjątkowy szacunek, jaki żywił do tego ostatniego, pokazał podczas dyskusji nad zaćmieniem słońca w 1239 r. (Historia, par. 39). Po skończonych studiach w 1246 r., został wychowawcą cesarza Teodora II (1254-1258). Pełnił bardzo wysokie funkcje cywilne w aparacie władzy Cesarstwa oraz był delegowany do misji dyplomatycznych (Epir, Trnovo, Lyon, Trapezunt). Poślubił Eudokię, krewną cesarza Michała (brak bardziej precyzyjnych danych odnośnie pokrewieństwa, 1255 r.?). Mieli dwóch własnych synów: Konstantyna i Melchizedeka, oraz chrzestnego, Jerzego Ibera. W latach 60. A. był nauczycielem filozofii i matematyki w Szkole Patriarchatu. Bliżej nieokreślone

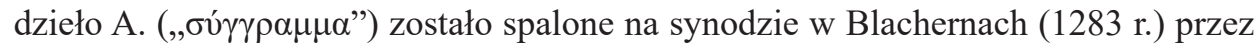
przeciwników unii. ${ }^{3}$ Jakkolwiek kontekst sugeruje jakieś prace teologiczne, nie jest wykluczone, że ucierpiała także Historia, opus magnum A., której zachowany tekst urywa się gwałtownie (nie wiadomo zatem, czy A. nie zdążył jej ukończyć/poprawić przed śmiercią, czy też jej stan obecny zawdzięczamy czynnikom zewnętrznym).

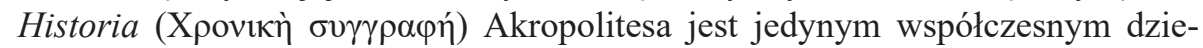
łem historiograficznym (kronika świata Teodora Skutariotesa, kończąca narrację na 1261 r., jest późniejsza), opisującym wydarzenia lat 1203-1261. Pomimo silnego akcentu autobiograficznego pozostaje fundamentalnym, a przy tym wiarygodnym ${ }^{4}$ źródłem do dziejów tzw. Cesarstwa Nicejskiego oraz innych struktur sukcesyjnych, powstałych po katastrofie 1204 r. na Bałkanach i w Anatolii. Historia reprezentuje polityczną perspektywę Paleologów, jakkolwiek dokładniejsze aniżeli post 1261 r. określenie jej powstania nie jest obecnie możliwe. Stosunkowo łatwo natomiast można wskazać autorów, dla których $H$. była źródłem dla ich własnej twórczości: Teodora Skutariotesa, Efraima, Nikefora Gregorasa, Makarego Melissenosa (zwł. prooimion). Celem $H$. jest obiektywna relacja współczesnych

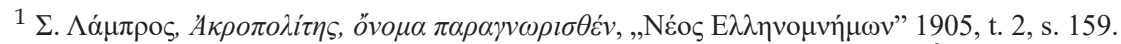

2 A. Oikonomou-Laniado, Un sceau de Georges Akropolite trouvé à Argos, RÉB 1997, t. 55, s. $291-$ 294. Zdaniem Ruth Macrides, George Akropolites, the history, translated with an introduction and commentary, Oxford 2007, s. 7, przyp. 23, kontekst archeologiczny jest zbyt wczesny na autora Historii.

3 Pachymeres, 3.35-37. Immaculada Pérez-Martín wysunęła hipotezę, że Ambrosianus M71 supp. (525), może pochodzić od rękopisu, zawierającego teologiczne rozprawy A., Le conflit de l'Union des Églises (1274) et son reflet dans l'enseignement supérieur de Constantinople. „Byzantinoslavica” 1995, t. 56, s. 411-422, tu: s. 412-413.

${ }^{4}$ Macrides, op. cit., s. 39 nn.
} 
autorowi wydarzeń, podkreślająca wszakże, iż władcy Nicei są jedynymi legalnymi sukcesorami Cesarstwa po katastrofie 1204 r. Materiał narracyjny (podzielony na 89 paragrafów) zorganizowany jest chronologiczno-geograficznie (,wschód” [Anatolia] i ,zachód” [Bałkany]). Jego zakres tematyczny jest stosunkowo wąski i ogranicza się, z nielicznymi wyjątkami, do kwestii polityczno-wojskowych. Bardzo silny akcent biograficzny, obecny w dziele, jest naturalną pochodną biografii A., jakkolwiek dwa paragrafy mają ściśle osobisty charakter (par. 29: przybycie do Nicei, par. 32: przedstawienie nauczycieli). Jako wysoki urzędnik państwa Laskarysów, w tym dyplomata, brał on bezpośrednio udział w wielu opisywanych wydarzeniach (często A. podkreśla ten fakt, by zapewnić o wiarygodności przekazu); miał też łatwy dostęp do źródeł dokumentowych, których część sam zresztą współtworzył. Jedynie zatem do opisu najwcześniejszych wydarzeń potrzebował źródeł narracyjnych. Nadal pozostają one niezidentyfikowane, ale z pewnością nie należała do nich Kronika Niketasa Choniatesa ze względu na zbyt dużą rozbieżność w przedstawieniu niektórych faktów. ${ }^{5} H$. jest dziełem klasycyzującym. Tendencję powyższą na poziomie struktury reprezentuje a) charakter wstępu (proimion, par. 1): odwołanie do poprzednich dzieł i wyznaczenie celów własnego (np. pisanie sine ira et studio, Polib. 1.14), b) obecność mów, spełniających funkcję wzmacniania argumentacji oraz c) znakomity, niezwykle ścisły z medycznego punktu widzenia, opis choroby cesarza Jana III (użycie terminologii Galena, par. 52); na poziomie języka świadczą o niej a) znormalizowana bizantyńska koine ${ }^{6}$ oraz b) częste, aczkolwiek typowe dla ówczesnej prozy historiograficznej, archaizmy. Oprócz powyższego opus magnum Akropolites był również autorem pomniejszych tekstów, z których zachowały się: wersy na ikonę Marii, 1246-1254, ${ }^{7}$ nieopublikowane enkomion św. Jerzego, ${ }^{8}$ wstęp do edycji zbioru listów Teodora II z $1253,{ }^{9}$ epitafium ku czci cesarza Jana III Dukasa Watatzesa z $1254,{ }^{10}$ dwie mowy na

\footnotetext{
${ }^{5}$ Macrides, op. cit., s. 36-38.

${ }^{6}$ Jest to termin dość umowny, gdyż u każde autora występują specyficzne cechy rejestru. Niedawne badania futurum i modalności w prozie Akropolitesa wykazały, że zachowuje on klasyczną morfologię, ale na poziomie syntaksy funkcjonuje ona zgodnie z ususem współczesnym autorowi, zob. Geoffrey Horrocks, Georgios Akropolitis: theory and practice in the language of later Byzantine historiography. „Byzantios” 2017, t. 12, s. 109-118.

${ }^{7}$ Georgii Acropolitae Opera, rec. August Heisenberg, 2 Bde. Leipzig 1903; editionem anni MCMIII correctiorem curavit Peter Wirth. Stutgardiae 1978, Bd. 2, s. 6-7. Oprócz thumaczenia angielskiego R. Macrides, dysponujemy także tłum. ros. (П. И. Жаворонков, пер., вступ. ст., комм., Георгий

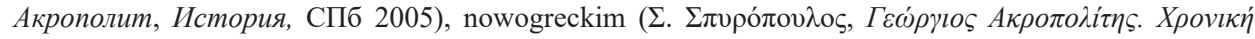

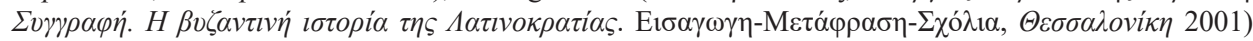
i niemieckim (Wilhelm Blum, Georgios Akropolites (1217-1282). Die Chronik [BGL 28], übersetzt und erläutert von, Stuttgart 1989).

8 Wspomina o nim syn Konstantyn, ep. 96, ed. Delehaye, pisząc przyjacielowi, że go nie ma. Enkomion zachował się w rękopisie z Wielkiej Ławry i wciąż oczekuje na edycję krytyczną, zob. Spyridon of Laura, S. Eustradiades, Catalogue of the Greek manuscripts in the libary of the Laura on Mount Athos, Cambridge 1925, s. 46-47, no. 339, f. $213^{\text {r }}$.

${ }^{9}$ Georgii Acropolitae..., Bd. 2, s. 7-9.

10 Ibidem, Bd. 2, s. 12-29; V. Valdenberg, Notes sur l'oraison funèbre de G. Acropolite. BZ 1929-30, t. 30, s. 91-95; Karl Praechter, Antikes in der Grabrede des Georgios Akropolites auf Johannes Dukas.
} 
Ducha Św. (napisane w więzieniu w Epirze, w $1.1257-1259),{ }^{11}$ list do Jana Tornikesa, po $1261^{12}$, wyjaśnienia do Or. 29 Grzegorza z Nazjanzu, po $1261,{ }^{13}$ enkomion Piotra i Pawła, ca. $1274 .{ }^{14}$ Zachował się też dokument z 1277 r. z jego podpisem, wystawiony dla Chilandaru. ${ }^{15}$ Do utworów przypisywanych A., ale obecnie uważanych za nieautentyczne, należą: wersy na grób cesarzowej Ireny (zm. 1239), córki Teodora I i żony Jana III, ${ }^{16}$ sticheron ${ }^{17}$ oraz leksykon. ${ }^{18}$ Natomiast $\mathrm{z}$ utworów niezachowanych wymienić należy wyżej wspomnianą, spaloną rozprawę teologiczną (być może jedną z wielu), trzynaście modlitw na uroczyste wejście do Miasta 15 sierpnia 1261, wreszcie mowę dla cesarza Michała VIII z $1261 \mathrm{r}$.

\section{FRAGMENTY}

Wszystkie trzy omawiane tu fragmenty z zakresu geografii historycznej Wlachii dotyczą zmiany władzy nad Macedonią i Tesalią w drugim dwudziestoleciu XIII w. Po chaosie pierwszych lat od halosis, na początku lat 20. tereny te zdołał opanować Teodor Komnen. Kres władzy epirockiej przyniosła bitwa pod Kłokotnicą (wieś, leżąca ok. $5 \mathrm{~km}$ na północny zachód od $\mathrm{m}$. Chaskowo; 9 marca 1230: datę dzienną podaje inskrypcja w cerkwi Czterdziestu Męczenników w Tyrnowie), w wyniku której obszary te przejęli Bułgarzy. Zwycięska rekonkwista Jana III Watatzesa miała miejsce jesienią $1246 \mathrm{r}$. W listopadzie br. zajął Tesalonikę. Podczas tej wyprawy cesarzowi towarzyszył Akropolites, odpowiedzialny za wysyłanie rozkazów do lokalnej

BZ 1905, t. 14, s. 479-491.

11 Georgii Acropolitae..., Bd. 2, s. 30-66; G. Richter, Des Georgios Akropolites Gedanken über Theologie, Kirche und Kircheneinheit. „Byz” 54 (1984), s. 276-299.

${ }^{12}$ Georgii Acropolitae..., Bd. 2, s. 67-69.

13 Ibidem, Bd. 2, s. 70-80; J. Dräseke, Neuplatonisches in des Gregorios von Nazianz Trinitätslehre, BZ 1906, t. 15, s. 140-160.

14 Georgii Acropolitae..., Bd. 2, s. 81-111: w 1274 r. dla Marinusa, abpa Eboli. Deno J. Geanakoplos: po powrocie z Lyonu w celu wsparcia unii, zob. Bonaventura, the two mendicant orders, and the Greeks at the council of Lyons (1274), ,Studies in Church History” 1976, t. 13, s. 183-211.

15 Actes de Chilandar I, nr 10, 135-138, podpis 138.27 (przywileje nadane przez Aleksego III).

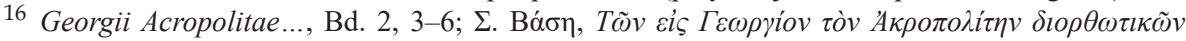

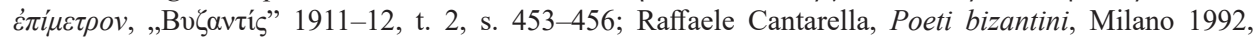
t. 2, s. 922-931: autent., śmierć Ireny: 1241, jednak podstawą datacji śmierci jest wzmianka o zaćmieniu słońca w Historii, co większość badaczy skłania ku 1239; contra: Wolfram Hörandner, ProdromosReminiszenzen bei Dichtern der nikäischen Zeit, BF 1972, t. 4, s. 88-104 (nowa edycja); Praechter, BZ 1904, t. 13, s. 524-531 (recenzja edycji Heisenberga). Ms. Cod. Laur. conv. soppr. 627, nt. ms.: Ben E. Perry, The Greek source of some Armenian fables, [w:] Polychronion. Festschrift Franz Dölger zum 75. Geburtstag, Heidelberg 1966, s. 418-430.

17 Georgii Acropolitae..., Bd. 2, s. 9-11. Blemmydes?

18 Bibliothèque nationale suppl. gr. 1089 (saec. XVI) podaje za autora A., ale inna redakcja jest anonimowa, zob. C. Astruc, M. L. Concasty, Catalogue des manuscrits grecs. Le Supplément grec III/3. Paris 1960, s. 209; E. Miller, Lexiques grécs inédits, „Annuaire de 1’Association des études grecques” 1874, t. 8, s. 222-284, tu: s. 253 . 
administracji (par. 44). Pełnił też później funkcję ambasadora w Tyrnowie w 1. 12601261. Akropolites konsekwentnie nie zauważa ludności wołoskiej, a terminu „Wielka Wlachia" używa jako neutralnego terminu geograficzno-administracyjnego. Najstarsze poświadczenie geograficznego terminu 'Wlachia' (provintia Blachie) to chrysobulla Aleksego III Angelosa dla Wenecjan z listopada 1198 r., której tekst łaciński zachował się w dwóch rękopisach archiwum weneckiego. ${ }^{19}$ Zostaje ono następnie wykorzystane przy sporządzeniu partitio Romaniae z $1204 \mathrm{r}^{20}$ Obejmuje ona tereny wokół Lamii, Domokos (oba miasta to już Ftiotyda), Halmyros (płd.-wsch. Tesalia) oraz góry Otrys - pogranicze Ftiotydy i Magnezji. Pierwotnie (2 poł. XI w., por. powstanie 1066 r. u Kekaumena) termin Wlachia oznaczał rejon wschodniej i południowej Tesalii (najbardziej na zachód: Larissa, a następnie Farsalos czy Halmyros), wraz z pogranicznymi rejonami Ftiotydy (od południa; Ypati [Neai Patrai], Lamia [biz. Zetounion], Domokos,) oraz Magnezji (od wschodu; Wolos/Demetrias, góra Otrys). Ze względu na charakter poświadczenia źródłowego nabrał on znaczenia administracyjnego. Dodany przymiotnik „Mçó $\lambda \eta ”$ okazał się potrzebny ze względu na

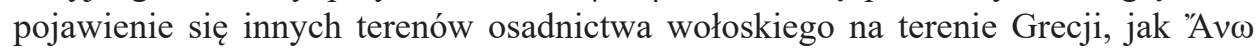

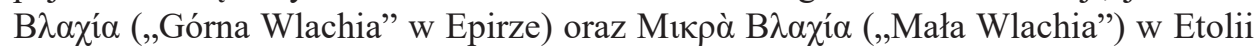
i Akarnanii. ${ }^{21}$ Tak też definiuje termin ,wielka Wlachia” Choniates, który stosuje go

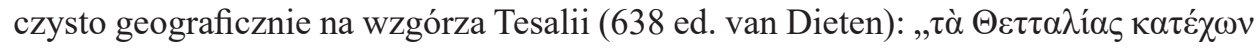

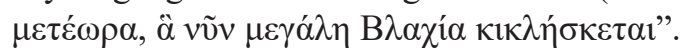

Fragm. 1: 1230 r. (par. 25, Heisenberg-Wirth 42.22-43.3)

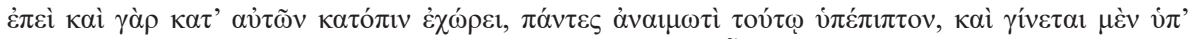

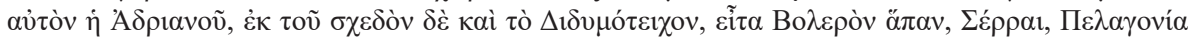

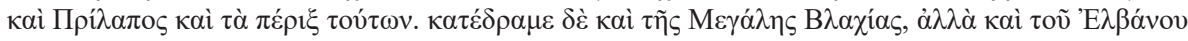

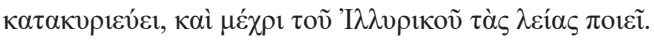

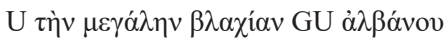

Gdy więc wyruszył [Jan Asen II, 1218-1241] następnie przeciw nim, wszyscy podporządkowali mu się bez rozlewu krwi: a zwłaszcza miasto Hadriana; także okolice ${ }^{22}$ Didymoteichon, ${ }^{23}$ całe

19 Blum mylnie: „stammt aus dem 13. Jahhundert”. Anmerkung 52, s. 218.

${ }^{20}$ Antonio Carile, Partitio terrarum Imperium Romaniae, „Studi Veneziani” 1965, t. 7, s. 127-305.

${ }^{21}$ G. C. Soulis, The Thessalian Vlachia, ZRVI 1963, t. 8, s. 271-273.

22 Macrides: „about the same time” ale słusznie Blum: „aus der Umgebung”. Jakkolwiek obie możliwości są gramatycznie i semantycznie poprawne, to analiza całej frazy w twórczości Akropolitesa

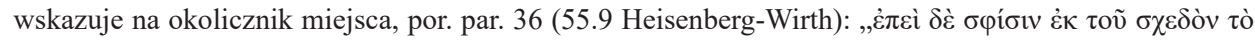

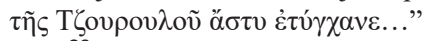

${ }_{23}$ Obecnie Didimoticho nad Hebrosem/Maricą, ok. $30 \mathrm{~km}$ na południowy wschód od Adrianopola (obecnie Edirne). 
Boleron, ${ }^{24}$ Serrai, ${ }^{25}$ Pelagonię, ${ }^{26}$ Prilapp ${ }^{27}$ i okolica tychże. Najechał też [ziemię] Wielkiej Wlachii, podporządkował Elbanon i złupił teren aż po Illyrikon. ${ }^{28}$

Komentarz: Bitwa pod Kłokotnicą pomiędzy Janem II Asenem a Teodorem Komnenem. Miejsce bitwy znane tylko dzięki Akropolitesowi oraz Skutariotesowi (474.17). Po jej zakończeniu autor detalicznie opisuje przemarsz Asena na linii wschódzachód (niezależne źródło wzmiankujące te ośrodki, jako zajęte przez Asena, to dokument tegoż dotyczący przywilejów handlowych dla Dubrownika z tegoż roku, ${ }^{29}$ „wielkiej Wlachii” - brak mimo, że jest Sołuń [Tesalonika] jako kierunek handlu). Pada tutaj sformułowanie „Wielka Wlachia”. Elbanon to wg Spyropoulosa ${ }^{30}$ albański Elbassan. Jest to błędne, gdyż forma Elbanon jest skądinąd nieznana. Inne lekcje (p. wyżej) oraz źródła (Skutariotes, 474.31; Efraim, 8115) jednoznacznie wskazują formę Albanon, znany skądinąd górzysty region na via Egnatia, między Dyrrachion a Ochrydą. ${ }^{31}$ Pod władzą Epiru od przynajmniej 1217 r.

Fragm. 2: 1237 r. (par. 38, Heisenberg-Wirth 61.19-62.4)

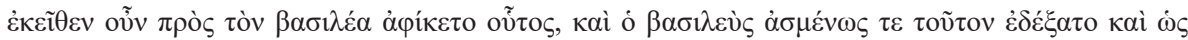

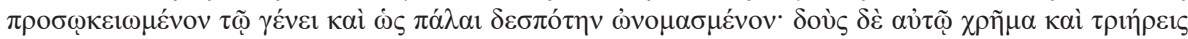

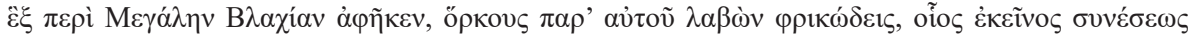

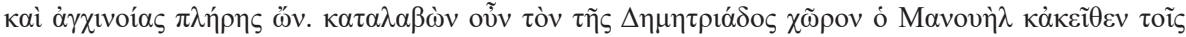

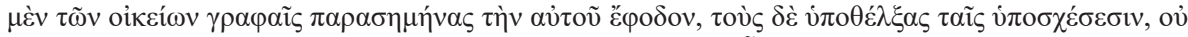

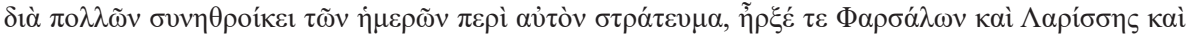

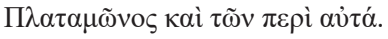

Stamtąd zatem, przybył on do cesarza [Jana III Watatzesa], a cesarz przyjął go z życzliwością, jako osobę spokrewnioną i noszącą dawniej tytuł despotesa. Dawszy mu pieniądze i sześć trier, wysłał do Wielkiej Wlachii, odebrawszy odeń solenne przysięgi, jako że był on [cesarz] człowiekiem roz-

24 Tem Boleron, istniejący od XI w. Obejmował on większą część trackiego wybrzeża, od Christoupolis (obecnie Kaballa) na zachodzie, po Makre (wieś $12 \mathrm{~km}$ na zachód od Aleksandroupolis; łączona, choć nie ma tu pewności, z antyczną Ortagoreją, zob. M. H. Hansen, Th. H. Nielsen (red.), An Inventory of archaic and classical poleis, New York 2004, s. 872, 880) na wschodzie i góry Papikion na północy. W chrysobu1li Aleksego III (1198) Boleron jest częścią temu „Boleronu, Strymonu i Tesaloniki”.

${ }^{25}$ Obecnie Serres, miasto nad Strymonem.

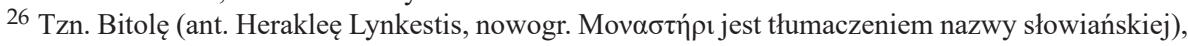
a nie równinę o tej samej nazwie.

27 Obecnie Prilep (Macedonia Północna), ok. 40 km. na północ od Bitoli (ant. Heraklea Lynkestis, nad rz. Dragor, prawym dopływem rz. Crna [ant. Erigon]), północny rejon równiny Pelagonii, por. Kravari, 319-322.

${ }^{28}$ Ogólne określenie terytorium na północ od Epiru.

29 Д. Живојиновић, Хоризма бугарског иара Јована Асена II Дубровнику, „Initial. A Review of Medieval Studies" 2013, t. 1, s. 229-239 (edycja krytyczna).

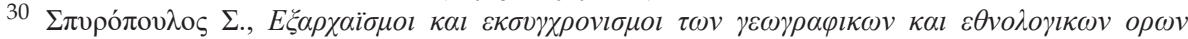

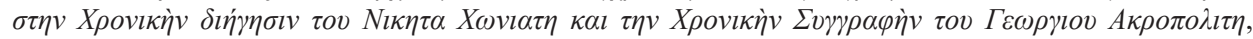
$\Theta \varepsilon \sigma \sigma \alpha \lambda$ ovíkп 2010, s. 183, przyp. 111.

${ }^{31}$ A. Ducellier, L'Arbanon et les Albanais au XI' siècle. TM 1968, t. 3, s. 353-368. 
umnym i przebiegłym. Manuel, po zejściu na ląd w rejonie Demetrias, ${ }^{32}$ powiadomił stamtąd pisemnie niektórych ze swoich ludzi o przybyciu, innych zaś omamił obietnicami, tak że w niewiele dni zgromadziło się wokół niego wojsko; przejął władzę nad Farsalos, Larissą, ${ }^{33}$ Platamon $^{34}$ i terenami je okalającymi. ${ }^{35}$

Komentarz: Pobyt Manuela Komnena (zm. 1239 r.) w Wielkiej Wlachii po wygnaniu przez brata, cesarza Teodora Komnena (1237 r.). Wielka Wlachia jako Tesalia.

\section{Fragm. 3: 1246 r. (par. 44, Heisenberg-Wirth 76.1-4)}

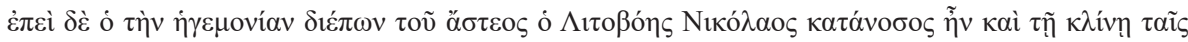

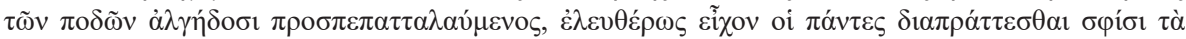

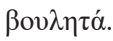

Ponieważ ten, który sprawował władzę w mieście [tzn. w Melniku], Litoboes Nikolaos, zachorował i ze względu na ból stóp był przykuty do łóżka, wszyscy robili, co chcieli.

Komentarz: Postać Mikołaja Litovoesa, namiestnika Melnika, podczas wyprawy cesarza Jana III Watatzesa w 1246 r. Dragotas ${ }^{36}$ - dowódca wojskowy Serrai, przybywa do Melnika, ${ }^{37}$ by podporządkować miasto cesarzowi. Ze względu na niemoc tam-

32 Obecnie Wolos nad Zatoką Pagazyjską. Główny ośrodek gospodarczy dla Tesalii i Magnezji, por. Alkiviadis Ginalis, The Pelion Peninsula - Byzantine port networks along inhospitable coastlines, „Byzantios” 2017, t. 11, s. 3-35; Panagita Asimakopoulou Atzaka, Early Christian and Byzantine Magnesia, [w:] Magnesia. The Story of a civilization, Athens 1982, s. 107-176.

${ }^{33}$ Anna Komnena wzmiankuje o wiosce wołoskiej Ezeban, leżącej blisko Andronii, między Larissą

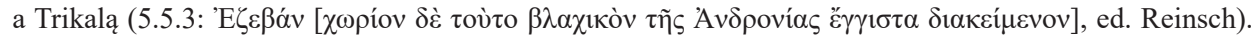
Wołosi pod Larissą są wzmiankowani już w II poł. XI w., w tym także w kontekście mniejszych ośrodków,

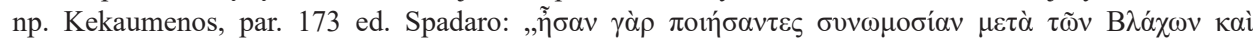

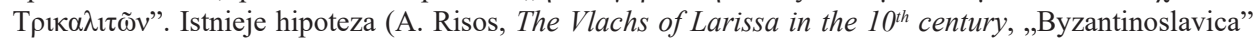
1990, t. 51, s. 202-207), że mogą się oni kryć pod i $\tau \alpha \lambda ı \tilde{\omega} \tau \alpha$ z z Miracula s. Demetrii (trzecia, anonimowa księga, PG 116, szp. 1389; epizod datowany na lipiec 904 r. [określenie to może nawiązywać do hipotezy Kinnamosa o pochodzeniu Włachów jako migrantów z Italii, p. niżej]). Andronia - locus incertus. Por. etnonim „Arvanitovlachoi” obecny w Tesalii i Akarnanii. Pod Larissą leży wioska

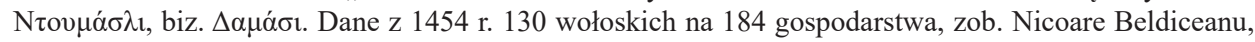
Petre S. Nasturel, La Thessalie entre 1454/55 et 1506, „Byzantion” 1983, t. 53, s. 104-156. Antonios Risos napisał jeszcze dwa bardzo ciekawe, wartościujące informacyjnie teksty, niezwiązane bezpośrednio z omawianą tu problematyką: Die Vlachen und ihre Pită, „Byzantinoslavica” 1992, t. 53, s. 233-236 oraz Zur Bevölkerungsgeschichte Thessaliens anhand der Häufigkeit gewisser Konsonanten in dortigen Familiennamen der Gegenwart, ,Südost-Forschungen” 2002, t. 61-62, s. 49-76.

${ }^{34}$ Ant. Herakleion, nieopodal ujścia rz. Penejos, na wybrzeżu Pierii (płd.-wsch. Macedonia), $25 \mathrm{~km}$ na południowy wschód od zboczy Olimpu.

35 Zwróćmy uwagę, że obok centralnego ośrodka w Larissie, pozostałe ośrodki wskazują poszczególne kierunki geograficzne. Brakuje wschodu, gdzie można mówić o Stagoi (znane od X w., dzis.

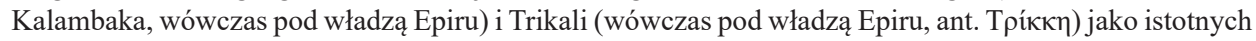
ośrodkach miejskich. Wymienione ośrodki leżały w granicach Wielkiej Wlachii.

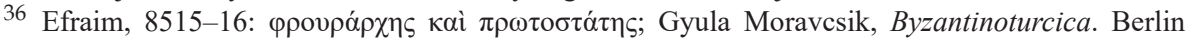
1983, Bd. II, s. 120.

37 Twierdza po wschodniej stronie doliny Strymonu, ok. $40 \mathrm{~km}$ na północ od Serrai, por. Mihailo Popović, Die Siedlungsstruktur der Region Melnik in Spätbyzantinischer und Osmanischer Zeit, ZRVI 
tejszego dowódcy bułgarskiego, lokalne elity greckie przekazały Dragotasowi miasto. Litovoes (słow. Litowoj, „dzielny wojownik”?) to imię kojarzone z Włachami. U Kekaumena znajdziemy Włachów noszących imiona słowiańskie z grecką koń-

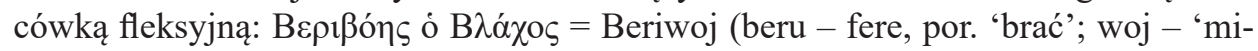

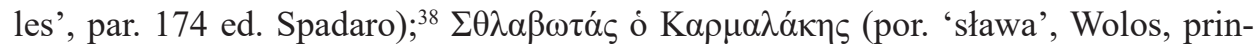
ceps Vlachorum, par. 181 ed. Spadaro); ${ }^{39}$ imiona ze słowiańską końcówką fleksyjną:

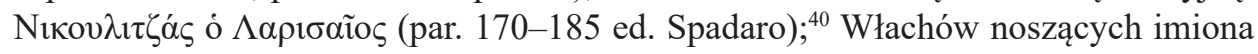

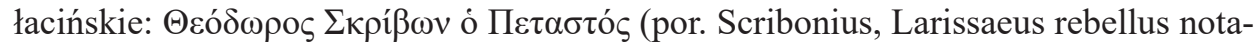
bilis, par. 181 ed. Spadaro). ${ }^{41}$ Choniates (430.27 ed. van Dieten) wspomina L., wziętego do niewoli, a później biorącego udział w wyprawie Izaaka II przeciw Wołochom w 1190-1191 (o czym Akropolites milczy), por. też Vatopedi I. 60. 325. W XIII w. spotykamy też dwóch Litowojów, wojewodów północnej Oltenii (dolina Haţeg, Râmnicu-Vâlcea). Litowoj I poświadczony jest w źródłach ok. 1247 r. (najazd mongolski 1241); Litowoj II, prawdopodobnie jego syn, zbuntował się przeciw Węgrom w 1264 r. a zm. w 1279 r. ${ }^{42}$ Georgius Baksa w imieniu bana Sewerinu spustoszył wówczas i złupił jego ziemie. ${ }^{43}$

\section{KONCEPCJA POCHODZENIA WŁACHÓW}

Jerzy Akropolites, podobnie jak Niketas Choniates, nie czyni najmniejszej wzmianki o tzw. „rzymskim pochodzeniu” Włachów, co prawdopodobnie należy wiązać z kryzysem tożsamościowym po halosis. Koncepcja rzymskiego pochodzenia Włachów związana jest z ówczesną percepcją ich języka. Pojawia się ona najprawdopodob-

2010, t. 47 (2010), s. 247-276; idem, Zur Topographie des spätbyzantinischen Melnik, JÖB 2008, s. 107119; Idem, Melnik - Geschichte und Denkmäler einer Stadt an den Ausläufern des Pirin-Gebirges, „Bulgaren in Österreich” 2008, t. 11, s. 16-18; V. Neševa, Melnik. Bogožidanijat grad, Sofia 2008; Zdravko Pljakov, La region de la Moyenne Struma aux XIII -XIV siècles, „Bulgarian Historical Review” 1986, t. 2, s. 56-73; Idem, Die Stadt Sandanski und das Gebiet von Melnik und Sandanski im Mittelalter, „Byzantinobulgarica” 1973, t. 4, s. 175-201; Ivan Dujčev, Melnik au moyen âge, „Byzantion” 1968, t. 38, s. 28-41; T. N. Vlachos, Die Geschichte der byzantinischen Stadt Melenikon, Thessaloniki 1969.

38 Tłum. pol. A. Kotłowska, A. Brzóstkowska, Testimonia najdawniejszych dziejów Słowian, Warszawa 2013, z. 6 (Pisarze wieku XI), s. 88-89; Nt. Beriwoja: I. Vásáry, Cumans and Tatars. Oriental military in the Pre-Ottoman Balkans (1185-1365), Cambridge 2005, s. 21.

39 Tłum. pol. Testimonia..., s. 96-97. Nazwisko Karmalikes nosił ok. 1530 r. „wielki rhetor i kierownik Szkoły Patriarchatu" w Konstantynopolu, zob. Diether R. Reinsch, Die Macht des Gesetzbuches. Eine Mission des Megas Rhetor Antonios Karmalikes in der Walachei, „Rechtshistorisches Journal” 1987, t. 6, s. 307-323.

40 Tłum. pol., Testimonia..., s. 85-87, 91-101.

${ }^{41}$ Tłum. pol. Testimonia..., s. 96-97.

42 Alexandru Madgearu, The Mongol domination and the detachment of the Romanians of Walachia from the domination of the Hungarian Kingdom, „De Medio Aevo” 2018, t. 12, s. 217-238; idem, Voievodul Litovoi şi prima acţiune de unificare a statului muntean, „Revista de Istorie Militară” 2002, t. $71, \mathrm{nr} 3$, s. $42-46$.

43 Tudor Sălăgean, Transylvania in the second half of the thirteenth century, Leiden 2016, s. 127. 
niej w XII w. (nie zna jej jeszcze Kekaumenos, gdy pisze o ich trybie życia (par. 187 ed. Spadaro; Strategikon powstał w 2 poł. lat 70. XI w.), gdy Jan Kinnamos pisze (post 1176), że są to „osadnicy z Italii, z dawnych czasów”. Ta myśl pojawia się później w dokumencie procesowym w kancelarii Jana Apokaukosa, bpa Naupaktos (1199-1233), datowanym na 1222 r. (ed. N. Bees). Ideę powyższą wykorzystał Innocenty III w swej korespondencji: pisząc o rzymskim pochodzeniu Włachów miał nadzieję na konwersję Kalojana/Johanicy (grudzień 1199/styczeń 1200). Źródłem informacji papieskiej mógł być legat na Bałkanach Dominik, Grek z pochodzenia, archiprezbiter Brindisi; innym dyplomatą u Kalojana, który wcześniej przebywał w Serbii, był Jan z Casamari. Kluczowe zdania brzmią: „Nos autem, audito quod de nobili urbis Rome prosapia progenitores tui originem traxerint, et tu ab eis et sanguinis generositatem contraxeris et sincere devotionis affectum, quem ad apostolicam sedem geris quasi hereditario iure." (PG 214, szp. 825, szp. 1114-1115 = Fontes latini historiae Bulgaricae III, 308, 312, 314). ${ }^{44}$ Jest ona znana również samym Włachom, por. list Bazylego, abpa Tyrnowa z lata 1202 r. do papieża w celu uzyskania tytułu cesarskiego dla swego władcy: „(...) tamquam heredes descedentes a sanguine Romano.” (PG 215, szp. 1116 = Fontes latini historiae Bulgaricae III, 314). Nie ma jednak konsensusu wśród badaczy, co do znaczenia tych odwołań, niektórzy uważają, ${ }^{45}$ że „rzymskość” jest aluzją do ciągłości kulturowej i państwowości pierwszego państwa bułgarskiego.

\section{PROBLEM TERMINOLOGICZNY}

Zgodnie z konwencją archaizacji etnikonów, dominującą w historiografii bizantyńskiej, również Włachowie pojawiają się pod innym określeniem, na które wszakże nie mają wyłączności. Niketas Choniates (ca. 1217), określa Włachów Myzami (368 van

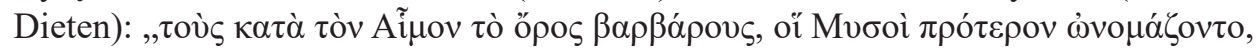

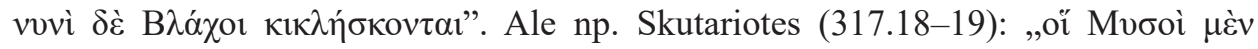

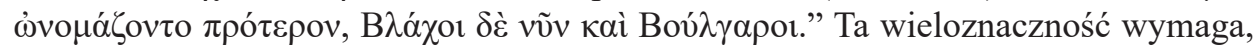
by przed ostateczną identyfikacją dokładnie badać kontekst źródłowy konkretnego przypadku. Interesujące, że koczowniczy tryb życia Włachów nie wystarcza do ich zdefiniowania. Stąd też wyraźnie podkreśla się ich odrębność od Kumanów, konsekwentnie zwanych Scytami (Choniates, 373 ed. van Dieten, 613 ed. van Dieten; Akropolites, par. 25 oraz 36). ${ }^{46}$

44 Także: Innocent III, ep. 255, [w:] Die Register Innocenz'III., t.. 2, red. O. Hageneder, W. Maleczek, A. A. Strnad, Rome-Wien 1979, 485; Dietmar Hintner, Die Ungarn und das byzantinische Christentum der Bulgaren im Spiegel der Register Papst Innozenz' III, Leipzig 1976.

${ }^{45}$ Florin Curta, Constantinople and the Echo Chamber: The Vlachs in the French Crusade Chronicles, „Medieval Encounters” 2016, t. 22, s. 427-462.

46 Por. szerzej: István Vásáry, Cuman Warriors in the Fight of Byzantium with the Latins, „Acta Orientalia Academiae Scientiarum Hungaricae" 2004, t. 57, s. 263-270. 
Otóż, co interesujące, etnonimikon Mysoi pojawia się u Akropolitesa dwukrotnie, lecz nie w Historii, a twórczości o charakterze retorycznym, a mianowicie w epitafios logos cesarza Jana III Watatzesa Dukasa (obiit 1254 r.). ${ }^{47}$ Jest to nom. sg. Múøos, jako personifikacja całego ludu. Podobnie zresztą autor stosuje też określenia: Perses, Tryballos, Dalmatos, Italos. Owa pars pro toto, nadająca całości wypowiedzi wrażenie uniwersalistycznej metafory, ma na celu wzmocnić przekaz o uniwersalności władzy cesarskiej, której podlegają rozmaite ethne. Nawiązania do tradycji klasycznej stają się jeszcze bardziej wyraziste, gdy spostrzeżemy opozycję Ausones/Rhomaioi. Przy czym ci pierwsi to oczywiście współcześni autorowi Łacinnicy. Poziom ogólności wypowiedzi, miejsce etnonimikonu w kontekście listy obcych ludów, ujarzmionych przez Rzym, jednoznacznie wskazuje, iż Mysos oznacza tutaj Bułgarów, a nie Włachów, z założenia dla Akropolitesa nieistniejących, gdyż stanowiących część Rzymian, obywateli Cesarstwa.

\section{ANEKS. EROTOKRITOS}

W pierwszych latach XVII wieku Witsentzos Kornaros ukończył swoje opus ma-

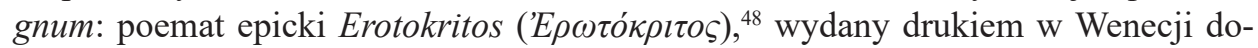
piero w 1713 r. Będący arcydziełem kultury kreteńskiej późnego okresu weneckiego, Erotokritos należy już do epoki nowożytnej. Dla omawianej problematyki istotny jest fakt, iż w księdze czwartej znajduje się epizod, w którym król Wlachii/Wlachów

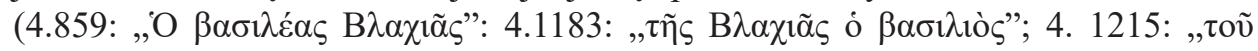

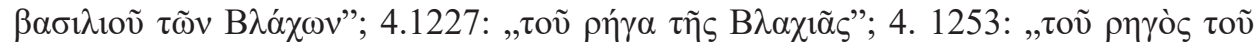

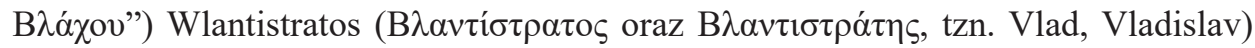
zaatakował Ateny. Nasz bohater, Rotokritos, zwyciężył w rycerskim pojedynku królewskiego siostrzeńca Aristosa, czym uratował miasto. Zważywszy na różnorodne źródła eposu (włoski przekład Owidiusza, romans bizantyński, a przede wszystkim Paris et Vienne Pierre'a de la Cypède ${ }^{49}$ ) i realia jego kompozycji nie należy raczej doszukiwać się w tym epizodzie konkretnego wydarzenia historycznego, mimo że takie próby podjęto. ${ }^{50}$ Wysoki poziom stylizacji zdaje się nie pozwalać na jednoznaczne ustalenia identyfikacyjne. Zagadnienie powyższe pozostaje wszakże dezyderatem badawczym.

47 Georgii Acropolitae..., Bd. 2, s. 13, 1.18 i s. 18, 1. 28.

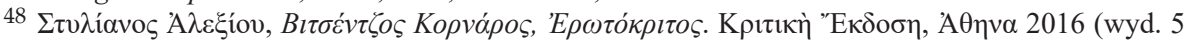
rozszerz.).

${ }^{49}$ R. Kaltenbacher, Der altfranzösischer Roman Paris et Vienne, Erlangen 1904.

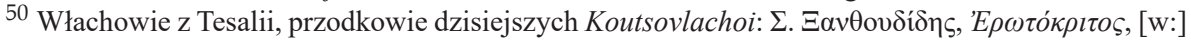

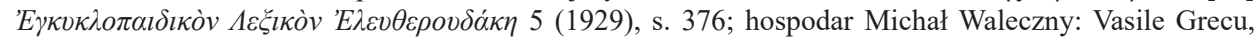
Erotocritul lui Cornaro in literatura romanesca, „Dacoromania” 1920, t. 1, s. 9-72; Alfred Vincent w wystąpieniu na sympozjum w Birmingham (1973). 


\section{SKRÓTY}

BF Byzantinische Forschungen

BZ Byzantinische Zeitschrift

JÖB Jahrbuch der Österreichischen Byzantinistik

PG Patrologia Graeca

PLP Prosopographisches Lexikon der Palaiologenzeit

RÉB Revue des Études Byzantines

ZRVI Zbornik Radova Vizantološkog Instituta

\section{BIBLIOGRAFIA}

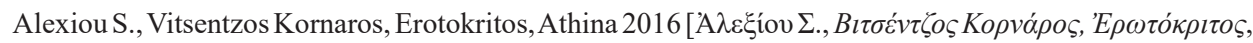
A $\theta$ ๆva 2016].

Asimakopoulou-Atzaka P., Early Christian and Byzantine Magnesia, [w:] Magnesia. The Story of a Civilization, Athens 1982.

Astruc C., Concasty M. L., Catalogue des manuscrits grecs. Le Supplément grec III/3, Paris 1960.

Beldiceanu N., Nasturel P. S., La Thessalie entre 1454/55 et 1506. „Byzantion” 1983, t. 53, s. 104-156.

Blum W., Georgios Akropolites (1217-1282). Die Chronik [BGL 28], übersetzt und erläutert von, Stuttgart 1989.

Cantarella R., Poeti bizantini. Milano 1992.

Carile A., Partitio terrarum Imperium Romaniae. „Studi Veneziani” 1965, t. 7, s. 127-305.

Curta F., Constantinople and the echo chamber: the Vlachs in the French crusade chronicles. „Medieval Encounters" 2016, t. 22, s. 427-462.

Dräseke J., Neuplatonisches in des Gregorios von Nazianz Trinitätslehre, BZ 1906, t. 15, s. 140-160.

Ducellier A., L'Arbanon et les Albanais au XI' siècle. TM 1968, t. 3, s. 353-368.

Dujčev I., Melnik au moyen âge. „Byzantion” 1968, t. 38, s. 28-41.

Georges Pachymérès: Relations historiques, red. A. Failler, V. Laurent, Paris 1984-2000, t. 1-5.

Geanakoplos D. J., Bonaventura, the two mendicant orders, and the Greeks at the council of Lyons (1274). „Studies in Church History” 1976, t. 13, s. 183-211.

Georgii Acropolitae Opera, rec. August Heisenberg, 2 Bde. Leipzig 1903; editionem anni MCMIII correctiorem curavit Peter Wirth, Stutgardiae 1978.

Ginalis A., The Pelion Peninsula - Byzantine port networks along inhospitable coastlines. „Byzantios” 2017, t. 11, s. 3-35.

Grecu V., Erotocritul lui Cornaro in literatura romanesca. „Dacoromania” 1920. t. 1, s. 9-72.

Hageneder O., Maleczek W., Strnad A. A. (red.), Die Register Innocenz'III, t. 2, Rome-Wien 1979.

Hansen M. H., Nielsen Th. H. (red.), An Inventory of archaic and classical poleis, New York 2004.

Hintner D., Die Ungarn und das byzantinische Christentum der Bulgaren im Spiegel der Register Papst Innozenz' III, Leipzig 1976.

Horrocks G., Georgios Akropolitis: theory and practice in the language of later Byzantine historiography. „Byzantios” 2017, t. 12, s. 109-118.

Hörandner W., Prodromos-Reminiszenzen bei Dichtern der nikäischen Zeit, BF 1972, t. 4, s. 88-104.

Kaltenbacher R., Der altfranzösischer Roman Paris et Vienne, Erlangen 1904.

Kotłowska A., Brzóstkowska A., Testimonia najdawniejszych dziejów Słowian, Warszawa 2013, z. 6 (Pisarze wieku XI).

Kravari V., Villes et villages de Macedoine occidentale, Paris 1989. 


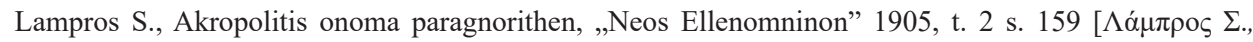

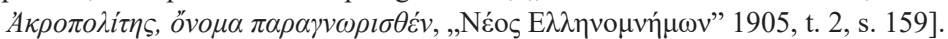

Macrides R., George Akropolites, the history, translated with an introduction and commentary, Oxford 2007.

Madgearu A., The Mongol domination and the detachment of the Romanians of Walachia from the domination of the Hungarian Kingdom, „De Medio Aevo” 2018, t. 12, s. 217-238.

Madgearu A., Voievodul Litovoi şi prima acțiune de unificare a statului muntean, „Revista de Istorie Militară" 2002, t. 71, nr 3, s. 42-46.

Miller E., Lexiques grécs inédits, „Annuaire de l'Association des études grecques” 1874, t. 8, s. 222 284.

Moravcsik Gy., Byzantinoturcica. 2. Bde, Berlin 1983.

Neševa V., Melnik. Bogožidanijat grad, Sofia 2008.

Oikonomou-Laniado A., Un sceau de Georges Akropolite trouvé à Argos, RÉB 1997, t. 55, s. 291-294.

Pérez-Martín I., Le conflit de l'Union des Églises (1274) et son reflet dans l'enseignement supérieur de Constantinople, „Byzantinoslavica” 1995, t. 56, s. 411-422.

Perry B. E., The Greek source of some Armenian fables, [w:] Polychronion, Festschrift Franz Dölger zum 75. Geburtstag, Heidelberg 1966, s. 418-430.

Pljakov Z., Die Stadt Sandanski und das Gebiet von Melnik und Sandanski im Mittelalter, „Byzantinobulgarica” 1973, t. 4, s. 175-201.

Pljakov Z., La region de la Moyenne Struma aux XIII $-X I V^{\bullet}$ siècles, „Bulgarian Historical Review” 1986, t. 2, s. 56-73.

Popović M., Die Siedlungsstruktur der Region Melnik in Spätbyzantinischer und Osmanischer Zeit, ZRVI 2010, t. 47, s. 247-276.

Popović M., Melnik - Geschichte und Denkmäler einer Stadt an den Ausläufern des Pirin-Gebirges, „Bulgaren in Österreich” 2008, t. 11, s. 16-18.

Popović M., Zur Topographie des spätbyzantinischen Melnik, JÖB 2008, s. 107-119.

Praechter K., Antikes in der Grabrede des Georgios Akropolites auf Johannes Dukas, BZ 1905, t. 14, s. 479-491.

Praechter K. [rec.], Georgii Acropolitae Opera, rec. August Heisenberg, 2 Bde, Leipzig 1903, BZ 1904, t. 13, s. $524-531$.

Reinsch D. R., Die Macht des Gesetzbuches. Eine Mission des Megas Rhetor Antonios Karmalikes in der Walachei, „Rechtshistorisches Journal” 1987, t. 6, s. 307-323.

Reinsch D. R., Kambylis A., Kolovou F. (red.), Annae Comnenae Alexias, Berolini 2001.

Risos A., Die Vlachen und ihre Pită, „Byzantinoslavica” 1992, t. 53, s. 233-236.

Risos A., The Vlachs of Larissa in the $10^{\text {th }}$ century, „Byzantinoslavica” 1990, t. 51, s. 202-207.

Risos A., Zur Bevölkerungsgeschichte Thessaliens anhand der Häufigkeit gewisser Konsonanten in dortigen Familiennamen der Gegenwart. „Südost-Forschungen” 2002, t. 61-62, s. 49-76.

Sălăgean T., Transylvania in the second half of the thirteenth century, Leiden 2016.

Soulis G. C., The Thessalian Vlachia, ZRVI 1963, t. 8, s. 271-273.

Spadaro M. D. (red.), Kekaumenos. Raccomandazioni e consigli di un galantuomo: Stratēgikon, Alessandria 1998.

Spyridon of Laura, Eustradiades S., Catalogue of the Greek manuscripts in the libary of the Laura on Mount Athos, Cambridge 1925.

Spyropoulos S., Exarhaismou kai eksyghronismoi ton geografikon kai ethnologikon oron stin Hronikin diigisin tou Nikita Honiati kai tin Hronikin Syggrafin tou Georgiou Akropoliti, Thesaloniki 2010

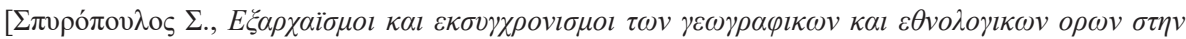

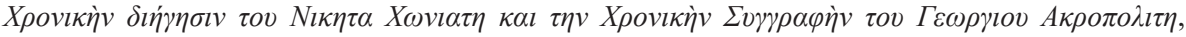
$\Theta \varepsilon \sigma \sigma \alpha \lambda$ ovík 2010].

Spyropoulos S., Georgios Akropolitis. Hroniki Syggrafi. I vyzantini istoria tis Latinokratias. Eisagogi-

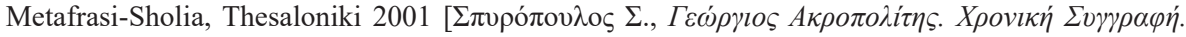

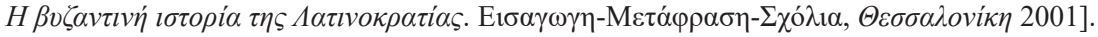


Valdenberg V., Notes sur l'oraison funèbre de G. Acropolite. BZ 1929-1930, t. 30, s. 91-95.

van Dieten J. L. (red.), Nicetae Choniatae Historia, Berolini et Novi Eboraci 1979.

Vásáry I., Cumans and Tatars. Oriental military in the pre-Ottoman Balkans (1185-1365), Cambridge 2005.

Vásáry I., Cuman Warriors in the fight of Byzantium with the Latins, „Acta Orientalia Academiae Scientiarum Hungaricae" 2004, t. 57, s. 263-270.

Vasi S., Ton eis Georgion ton Akropolitin diorthotikon epimetron, Vyzantis 1911-1912, t. 2, s. 453-456

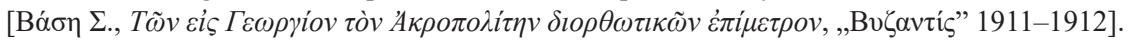

Vlachos T. N., Die Geschichte der byzantinischen Stadt Melenikon, Thessaloniki 1969.

Xanthoudidis S., Erotokritos, [w:] Egkyklopaidikon Lexikon Eleutheroudaki 5 (1929), s. 376 [ $\Xi \alpha v \theta o v \delta i ́ \delta \eta \varsigma$

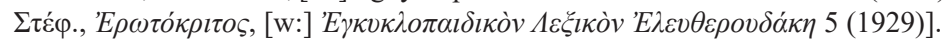

Žavoronkov P. I. (tłum., wstęp, koment.), Georgij Akropolit. Istorija [Жаворонков П. И., пер., вступ. ст., комм, Георгий Акрополит, История, СПб 2005].

Živojinović D., Horizma bugarskog cara Jovana Asena II Dubrovniku, „Initial. A Review of Medieval Studies" 2013, t. 1, s. 229-239 [Живојиновић Д., Хоризма бугарског иара Јована Асена II Дубровнику].

Živojinović M., Kravari V., Giros Ch., Actes de Chilandar. I. Des origines à 1319. Texte, Paris 1998. 